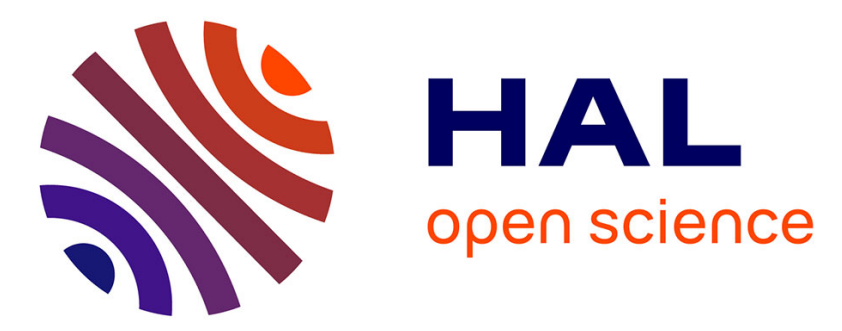

\title{
Calabresi: Heterodox Economic Analysis of Law
}

Alain Marciano, Giovanni Battista Ramello

\section{To cite this version:}

Alain Marciano, Giovanni Battista Ramello. Calabresi: Heterodox Economic Analysis of Law. Encyclopedia of Law and Economics, Springer New York, pp.1-4, 2018, 10.1007/978-1-4614-7883-6_726-1. hal-02306824

\section{HAL Id: hal-02306824 \\ https://hal.science/hal-02306824}

Submitted on 7 Oct 2019

HAL is a multi-disciplinary open access archive for the deposit and dissemination of scientific research documents, whether they are published or not. The documents may come from teaching and research institutions in France or abroad, or from public or private research centers.
L'archive ouverte pluridisciplinaire HAL, est destinée au dépôt et à la diffusion de documents scientifiques de niveau recherche, publiés ou non, émanant des établissements d'enseignement et de recherche français ou étrangers, des laboratoires publics ou privés. 


\title{
Calabresi, heterodox economic analysis of law
}

Alain Marciano, MRE and University of Montpellier

Giovanni Ramello, University of Eastern Piedmont

\begin{abstract}
Guido Calabresi is one of the founders of the law and economics movement. His approach, however, corresponds to a form of economic analysis of law that, we claim, is heterodox. We show why in this short notice.
\end{abstract}

\section{Biography}

Born October 18, 1932, in Milan, Guido Calabresi migrated with his family in the U.S.A. in 1939. After having received his Bachelor of Science degree (summa cum laude) from Yale College in 1953, majoring in economics, his Bachelor of Arts from Magdalen College at Oxford University in 1955, he got his Bachelor of Laws (LL.B.) magna cum laude from Yale Law School in 1958. Calabresi started by clerking for Justice Hugo Black, who was then United States Supreme Court Associate, from 1958 to 1959 and then joined the Yale Law School (instead of the University of Chicago Law School where he was offered full professorship). Calabresi was appointed United States Circuit Judge of the United States Court of Appeals for the Second Circuit in 1994. He still serves as Sterling Professor Emeritus and Professorial Lecturer in Law at the Yale Law School.

Law and economics emerged just after World War II, gained structure in the 1950s, took further shape in the 1960s, and established itself in the 1970s, essentially under the influence of economists and legal scholars from the so-called Chicago school. The use of economics as a parsimonious tool to tackle otherwise difficult and complex legal problems has now become so frequent that a number of scholars regard this as possibly the most important novelty in all of modern legal scholarship (Denozza, 2013; Mattei, 1994). 
It was Richard Posner who, formally, "invented" the economic analysis of law at the beginning of the 1970s when he published the discipline's eponymous masterpiece, launched the Journal of Legal Studies, and started to write articles in which he explained that economics is an important tool that can be used to analyze (in particular) legal phenomena. This accounts for the North-American, Anglo-Saxon origins of Law and Economics. But the field was from the outset a melting pot in the broadest sense - not just because it was a field of studies created at the intersection of economics and law, but also because it grew out of a blend of north American and European cultures (Ramello, 2016). Ronald Coase, another founders of Law and Economics was born in England. And Guido Calabresi was born in Italy, where he spent part of his childhood there. His family moved to the U.S.A to escape fascism, and brought with them a lively Italian and European bourgeois environment. Even if attempting to deduce impacts from historical backgrounds is generally a risky business (Kalman, 2014, p.15), there is strong evidence that Calabresi did indeed blend his family's european culture with that of the Us, and that this in turn had an influence on his scholarship. once, when asked what he considered to be the most important part of his legal education, Calabresi replied:

Ii am a refugee! and of course, how can I not have been influenced by the fact that we were antifascists and that we left Italy because my father had been jailed and beaten in 1923 and he was a democrat with a small 'd'; that we were very, very rich there and came here with nothing because it was against the law under penalty of death? if I write about capital punishment or if I make a decision, I am not going to be writing to push an agenda but, on the other hand, I would be pretty foolish not to be aware of the fact that that is in my background (Benforado \& Hanson, 2005, p. 75).

It is not our purpose, here, to look for and find specific traces of European elements in his work, but we nonetheless suggest that Calabresi's work evidences this European heritage. One major aspect of this heritage is what could be called the "comparative" dimension or the adoption of a "comparative viewpoint". This was in particular the case with "Some Thoughts on Risk Distribution and the Law of Torts" (Some Thoughts), Calabresi's first article. Written in the 50s when Calabresi was still a student, it was published in 1961. That was almost when Coase published his own path-breaking article, "The Problem of Social Cost" (1960). These 
two works are comparative in the sense that they were using the insights of another discipline to improve another one. While Coase was trying to improve his understanding of economic phenomena by relying on court cases, Calabresi was proposing to use economics to improve one's understanding of economic phenomena. In other words, with "Some Thoughts", Calabresi was probably the first to apply economic methods to analyze legal questions. He really initiated an original approach: of course different from what most legal scholars did, but also from what economists-Coase, for instance, or Aaron Director-started to do. Calabresi is not only a founder of the law and economics movement but also of an economic analysis of law.

Commentators on Calabresi's works perceived this innovation at the time of publication. For instance, Walter Blum and Harry Kalven observed the novelty of Calabresi's perspective as soon as they started to study and comment on his work, and noted that he had “crystallized the economic analysis of liability." $(1967,240)$ Posner himself also underscored the change of direction initiated by Calabresi with respect to Coase in his 1970 review of Calabresi's The Costs of Accidents. Moreover, in 1971 Frank Michelman, also commenting on The Costs of Accidents, noted that Calabresi "provide[s] a conceptual apparatus for describing, comprehending, and evaluating systems of accident law." Strictly speaking, Calabresi's approach was and remains a form of economic analysis of law, because he uses economics as a tool for analyzing legal issues (see Marciano, 2012).

Yet Calabresi himself continues to insist that his work should be viewed as a form of law and economics rather than as an economic analysis of law, and that he prefers to see his contribution grouped with Coase's rather than with Posner's, whom he strongly disagrees with and even opposes. In his most recent book, he anchored the distinction between his and Posner's approach - to put it differently, between law and economics and an economic analysis of law - in the opposition between Jeremy Bentham and John Stuart Mill. He also insists on the need for an economic approach to law should rest on a broader cognitive framework than the one used by neo-classical economists. Let us note this very claim was already present in "Some Thoughts", which is indeed remarkable not just because it is foundational for law and economics, but also because it is foundational for Calabresi. In this article, in accordance with the economic analysis of law, Calabresi used economics to guide legal action. But, on the other hand, he recognized that in certain settings "traditional economic theory [can] be of little help," he equally acknowledges the role of laws in fostering 
economic efficiency, as in the law-and-economics view. This twofold orientation not only places economics and law on an equal footing, it also treats them both as instruments serving higher goals connected with basic individual liberties, which the market alone is not always able to promote.

For instance, in a 2014 article, Calabresi explained the public function of torts: The liability rule (in both torts and in takings and eminent-domain law), is not used principally, much less solely, to approach the result that would occur in a free market of consensual exchanges (were such a market available), but is instead used approach inalienability (that is, a fully collective result) in those instances when a criminal-law solution is not desired. Calabresi expands on this argument by showing that the liability rule (of the collectively set price) is used to achieve goals that are neither purely libertarian nor purely collectivist, but are properly viewed as social democratic.

To understand Calabresi's approach, one must take into account the distinction between choice and consent. Usually, at least in neoclassical economics, individual choices are supposedly made under certain conditions, to which the choosers are assumed to implicitly consent. Consent is thus never discussed or considered in any way distinct from choice. The role of law is precisely to defend consent, and to intervene in an efficient way whenever this principle is violated.

Whereas standard economic analyses of law assume that choice means consent, Calabresi the discrepancy between choice and consent, which arises in many practical situations involving legal intervention. To him, the conditions of choice should not be treated as trivially exogenous features of the setting in which legal action-possibly guided by economic efficiency - is played out, but rather as a fully fledged part of the decision set, which the legal system must carefully consider. From this viewpoint it follows that the role of law and economics is to provide a method for examining these complex issues and arriving at solutions that consider not only social welfare (and, by implication, efficiency), but also other matters connected to individual rights and liberties.

Thus, Calabresi raised the problem of the potential lack of consent-arising from monopoly, individuals' lack of rationality, and their vulnerability to external pressures, or systemic imperfections — with the implication that individuals do not always make choices that correspond to their preferences. This in its turn enabled law-and-economics scholars to contribute by providing a wider framework for decision making that uses the efficiency 
criterion, but also explicitly combines it with other principles, such as societal welfare and individual liberties. The implication is that the questions social scientists have to tackle cannot always be reduced to optimal allocation of resources, and instead frequently require enquiring about the "starting points," conditions of choice, and consent to those conditions.

\section{Impact and legacy}

Calabresi is one of the founders of the law and economics movement and was even one of the first to suggest that economics could be used to analyse legal phenomena. One of his main insights and legacy is to have explained that and how law and economics complement each other. To him, economics is concerned with choice under certain given conditions that, as we have noted, may not be satisfactory. What economics provides is only a framework, which needs to be normatively qualified by judges and the legal system. Therefore, if for Calabresi, "law and economics proves the more challenging and worthwhile endeavor" than the economic analysis of law, it is because he envisages law and economics as a back-and-forth dialogue between the two disciplines. (Kalman, 2014) This equal footing of law and economics is what the economic analysis of law tends to preclude, because it essentially downgrades economics to a mere problem- solving technology. To be sure, Calabresi sees economics as providing road signs_- "road signs that are not too misleading to be worth spending time on" - that judges and lawmakers can then use to serve a higher good than simply fostering efficiency.

\section{Cross-references}

Economic Analysis of Law

Coase

Posner

\section{References}

Benforado A, J. Hanson (2005) The Costs of dispositionism: the premature demise of situationist economics. Maryland Law Review, 64, 24-84.

Blum W, H. Kalven, Jr. (1967) The Empty Cabinet of Dr. Calabresi: Auto Accidents and General Deterrence. University of Chicago Law Review, 34 (2), 239-273.

Calabresi G (1961) Some Thoughts on Risk Distribution and the Law of Torts. Yale Law Journal, 70(4): 499-553. 
Calabresi G (1971) The Costs of Accidents: A Legal and Economic Analysis, New Haven, Yale University Press.

Calabresi G (2014) A Broader View of the Cathedral: The Significance of the Liability Rule, Correcting a Misapprehension, Law and Contemporary Problems, 77 (2): 1-14.

Coase R (1960) The Problem of Social Cost. Journal of Law and Economics, 3, 1-44.

Kalman L (2014) Some Thoughts on Yale and Guido, Law and Contemporary Problems, 77 (2): $15-43$.

Marciano A (2012) Guido Calabresi's Economic Analysis of Law, Coase and the Coase Theorem, International Review of Law and Economics, 32: 110-118.

Marciano A, GB Ramello (2014) Consent, Choice and Guido Calabresi's Heterodox Economic Analysis of Law. Law and Contemporary Problems, 77 (2): 97-116.

Posner RA (1973) Economic Analysis of Law. Little, Brown and Co. New York.

Michelman F (1971) Pollution as a Tort: A Non-Accidental Perspective on Calabresi's Costs, Yale Law Journal,

Ramello GB (2016) The past, present and future of comparative law and economics," in: Giovanni Ramello (ed), Comparative Law and Economics, 3-22 Edward Elgar Publishing. 